\title{
PERBAIKAN MEDIA TANAM DENGAN PENGGUNAAN pH METER DAN MOISTURE METER PADA AGRIBISNIS TANAMAN HIAS
}

\author{
Agung Prasetyo*1, Mahananto ${ }^{2}$, Setie Harieni ${ }^{3}$, Achmad Fatchul Aziez ${ }^{4}$, \\ 1,2,3,4,5 Universitas Tunas Pembangunan Surakarta \\ *e-mail: agung.prasetyo@lecture.utp.ac.id
}

\begin{abstract}
ABSTRAK
Tujuan utama kegiatan pengabdian masyarakat ini adalah untuk menumbuhkan dan mengembangkan kesadaran pentingnya wirausaha dan memberikan pemahaman akan pentingnya media tanam terutamanya menyangkut $\mathrm{pH}$, kelembaban dan intensitas cahaya pada tanaman hias. Metode yang dipakai guna mencapai tujuan yang dimaksud adalah penyuluhan, pelatihan dan pendampingan pembuatan media tanam, penggunaan $\mathrm{pH}$ meter dan moisture meter. Penanaman bibit baru yang sudah disesuaikan dengan media tanam sesuai syarat hidup masingmasing tanaman hias. Hasil menunjukan bahwa Pelatihan perbaikan media tanam dengan menggunakan $\mathrm{pH}$ meter dan moisture meter mampu meningkatkan pengetahuan mitra akan $\mathrm{pH}$ tanah, kelembaban tanah dan intensitas cahaya beserta peranannya bagi kehidupan tanaman hias. Mitra dapat memilih dan mencampur masing-masing media tanam yang disesuaikan dengan jenis tanaman yang diusahakan. Pendampingan diperlukan lebih lanjut terutama menyangkut teknik manajemen tanaman hias karena penataan didalam lokasi usaha petani masih bercampur.
\end{abstract}

Kata kunci: Perbaikan, media tanam, pH Meter, moisture meter

\begin{abstract}
The main purpose of this community service activity is to grow and develop an awareness of the importance of entrepreneurship and provide an understanding of the importance of planting media, especially regarding $p H$, humidity, and light intensity in ornamental plants. The methods used to achieve the intended objectives are counseling, training, and assistance in the planting media, using pH meters and moisture meters. Planting new seeds that have been adapted to the growing media according to the life requirements of each ornamental plant. The results showed that training to improve planting media using a pH meter and moisture meter was able to increase partners' knowledge of soil pH, soil moisture, and light intensity along with their role in the life of ornamental plants. Partners can choose and mix each planting medium according to the type of plant being cultivated. Further assistance is needed, especially regarding ornamental plant management techniques because the arrangement in the farmer's business location is still mixed.
\end{abstract}

Keywords: Repair, planting media, pH meter, moisture meter

\section{PENDAHULUAN}

Dari sisi kemampuan sumberdaya, prospek agribisnis florikultura antara lain ditunjukkan dengan potensi bahwa Indonesia ialah daerah tropis yang mempunyai agroklimat tropis (daerah dataran rendah) serta agroklimat mirip subtropics (daerah dataran tinggi). Nyaris segala komoditas agribisnis florikultura di dunia bisa dibesarkan di Indonesia sebab keadaan kedua agroklimat tersebut. Kedua, kemampuan keragaman tipe florikultura sehingga keragaman tersebut nyaris dapat memenuhi seluruh segmen pasar florikultura internasional. Ketiga, kemampuan ketersediaan lahan untuk pengembangan tumbuhan hias di Indonesia yang masih lumayan luas sehingga ruang gerak pengembangan agribisnis yang relatif land based. Keempat, teknologi serta sumberdaya manusia buat pengembangan florikultura relatif ada. Pusat- pusat teknologi florikultura baik di lembaga pemerintah ataupun di akademi besar sudah tumbuh. Demikian pula sumberdaya manusia di mana keberagaman sumberdaya manusia bukan hambatan untuk pengembangan agribisnis melainkan kemampuan sebab tiap kualifikasi tenaga kerja mempunyai relung pada agribisnis florikultura (Tinaprilla \& Pratiwi, 2017). 
Sebagian besar tanaman bunga potong pada tahun 2017 mengalami peningkatan luas panen dibandingkan dengan tahun 2016. Peningkatan terbesar terjadi pada bunga krisan, yaitu sebesar 6,61 persen dari 1.091,42 hektar menjadi 1.163,55 hektar. Sedap malam adalah tanaman yang mengalami penurunan luas panen paling besar pada tahun 2017. Luas panen sedap malam mengalami penurunan sebesar 9,10 persen, yaitu dari 340 hektar pada tahun 2016 menjadi sebesar 309,07 hektar pada tahun 2017. Pakis, philodendron, dan pedangpedangan adalah tiga tanaman pot yang memiliki luas panen terbesar pada tahun 2017. Luas panen ketiga tanaman tersebut masing-masing adalah 90,89 hektar untuk pakis, 46,95 hektar untuk philodendron, dan 16,59 hektaruntuk pedang-pedangan. Sebagian besar tanaman pot mengalami penurunan produksi pada tahun 2017. Penurunan produksi yang paling tinggi terjadi pada philodendron dengan penurunan sebesar 6,44 juta pohon $(38,32$ persen) disusul dengan dracaena sebesar 2,31 juta pohon (49,22 persen), dan pakis sebesar 1,12 juta pohon (10,79 persen). Tanaman pot yang mengalami peningkatan produksi tertinggi, yaitu anthurium daun sebesar 616,06 ribu pohon (78,60 persen), soka sebesar 487,86 ribu pohon (89,87 persen), dan pedang-pedangan sebesar 382,39 ribu rumpun (47,23 persen). Untuk produksi tanaman hias lainnya, melati dan palem mengalami penurunan produksi sebesar 6,67 ribu ton (21,39 persen) dan 68,86 ribu pohon (7,01 persen) (Badan Pusat Statistik, 2018).

Provinsi Jawa Tengah merupakan provinsi penghasil tanaman hias yang cukup besar di Indonesia dengan jenis anthurium, adenium dan philodendron sebagai komoditas unggulannya. Produksi anthurium dan adenium pada tahun 2017 mencapai 101.161 pohon dan 86.495 pohon. Sedangkan dari jenis philodendron sebesar 861.368 pohon pada tahun 2017 (Badan Pusat Statistik, 2018). Tanaman hias memiliki nilai ekonomi yang tinggi (Kusno \& Andri, 2011) dan pada situasi pandemi Covid-19 yang sudah berlangsung sejak tahun 2020 sektor tanaman hias merupakan sektor yang berkembang baik ditengah sektor lain yang menurun tingkat pendapatannya. Sebagai sektor yang masih berkembang baik dalam memberikan tingkat pendapatan tentu produksi tanaman hias juga harus dijaga dan ditingkatkan. Salah satu faktor yang menentukan kelangsungan hidup tanaman hias adalah media tanam dari tanaman hias. Media tanam sebagai tempat pertumbuhan tanaman harus memenuhi unsur hara yang cukup. Pupuk organik yang diberikan pada media tanam salah satunya pupuk kandang. Pemberian pupuk kandang dapat memperbaiki sifat fisik, kimia dan biologi tanah. Penggunaan pupuk kandang lebih bermanfaat sebagai bahan pembenah tanah. Pupuk kandang mengandung $\mathrm{N}, \mathrm{P}$, dan $\mathrm{K}$ dalam jumlah yang relatif rendah, serta mengandung unsur hara mikro (Husnihuda, Sarwiti, \& Susilowati, 2017)

Desa Tawangmangu yang merupakan salah satu desa di Kecamatan Tawangmangu yang pada umumnya penduduknya berprofesi sebagai petani, pedagang, buruh (tani, industri ataupun perhotelan. Mayoritas penduduk Desa Tawangmangu yang umumnya berkerja sebagai petani dan buruh memiliki tingkat pendapatan rata-rata tergolong rendah, apalagi istri dari petani atau buruh tersebut tidak mempunyai pekerjaan tetap selain mengurus rumah tangga. Pertanian tanaman bahan makanan merupakan salah satu sektor dimana produk yang dihasilkan menjadi kebutuhan pokok hidup rakyat. Kecamatan Tawangmangu sebagian tanahnya merupakan tanah pertanian yang memiliki potensi cukup baik bagi pengembangan tanaman agro industri. Di Kecamatan Tawangmangu sangat potensial untuk tanaman hias (Badan Pusat Statistik, 2020).

Kegiatan pengabdian yang akan dilaksanakan milibatkan ibu-ibu rumah tangga Kelompok PKK (Pemberdayaan Kesejateraan Keluarga) Desa Tawangmangu, Kecamatan Tawangmangu sebagai mitra. Salah satu sumber daya alam yang sangat potensial adalah komoditas tanaman florikultura. Tanaman florikultura khususnya dari jenis tanaman hias mudah dibudidayakan dan memberikan ekonomi tinggi. Selama ini ibu-ibu PKK menanam tanaman hias hanya sebagai pajangan didepan rumah dikarenakan penghasilan utama dari ibuibu tersebut adalah sebagai pedagang di pasar wisata tawangmangu. Situasi pandemi virus 
corona atau covid-19 dewasa ini memaksa seluruh kegiatan perdagangan tidak mungkin untuk dilakukan seperti pada kondisi normal. Pengumpulan masa dalam jumlah banyak seperti dipasar akan dikurangi dan dilarang guna mencegah penyebaran virus. Kondisi ini tentu memaksa ibu-ibu PKK untuk beralih ke budidaya tanaman hias dikarenakan sektor tersebut masih memberikan peluang ekonomi yang cukup baik, bahkan baru-baru ini lelang dan bursa tanaman hias yang bertajuk Menggung Forest Art di Dusun Nglurah, Kelurahan Tawangmangu, Kecamatan Tawangmangu, Kabupaten Karanganyar, Jawa Tengah transaksinya tembus 1 Milyar selama 1 hari. Jenis tanaman yang dilelang di dominasi jenis Aroid yang sekarang ini lagi digandrungi pecinta Tanaman Hias. Dari mulai Marmorata, Philodendron varigata, P. Melanochrysum, Verokosum, Florida Beauty, Pink Princes, Epiprenum dan lain-lain (Garuda News, 2021).

Sebagai bagian dalam bisnis bunga media tanam menjadi hal yang utama dalam bisnis tanaman hias. Ibu-ibu PKK belum menggunakan $\mathrm{pH}$ meter dan moisture meter untuk mengukur $\mathrm{pH}$ dan kelembaban tanah. $\mathrm{pH}$ dan kelembaban tanah sangat menentukan keberhasilan kehidupan dari tanaman hias. Pengabdian ini diharpakan dapat memberikan pemahaman peningkatan sumber daya manusia terhadap penggunaan $\mathrm{pH}$ meter dan moisture meter sehingga dapat lebih menjamin kehidupan tanaman hias sehingga nantinya mampu memingkatkan pendapatan keluarga.

\section{METODE}

Metode yang digunakan adalah sosialisasi dan pelatihan terhadap peserta / mitra bapakbapak dan ibu-ibu Ortega Tawangmangu dengan menjaga dan menerapkan protokol kesehatan dalam suasana covid-19. Kegiatan dimulai dengan mengidentifikasi tingkat pengetahuan dan tingkat ketrampilan peserta tentang $\mathrm{pH}$, kelembaban dan cahaya bagi tanaman. Kegiatan dilanjutkan pemaparan penggunaan $\mathrm{pH}$ meter dengan metode ceramah dan diskusi, pembagian materi sosialisasi dan $\mathrm{pH}$ meter dan praktik secara langsung menggunakan pH meter dan moisture meter serta evaluasi. Kuisioner dilakukan sebelum dan sesudah penyampaian materi. Kuisioner setelah penyampaian materi merupakan evaluasi mengenai peningkatan pemahaman dan kemampuan sasaran dalam menggunakan $\mathrm{pH}$ meter moisture meter. Sosialisasi kemudian dilanjutkan dengan pelatihan tips dan trik memilih dan menggunakan media tanam sesuai dengan jenis tanaman beserta kelemahan dan kelebihan masing-masing media tanam.

\section{HASIL DAN PEMBAHASAN}

Pendampingan dilakukan dengan sosialisasi peran $\mathrm{pH}$ bagi tanaman dan pelatihan penggunaan $\mathrm{pH}$ meter. $\mathrm{pH}$ bagi tanaman berpengaruh pada ketersediaan unsur hara makro dan mikro dan berpengaruh terhadap penyerapan nutrisi. $\mathrm{pH}$ diatas 7.5 mempengaruhi ketersediaan zat besi $(\mathrm{Fe})$, manganese $(\mathrm{Mn})$, tembaga $(\mathrm{Cu})$, zinc $(\mathrm{Zn})$, boron $(\mathrm{B})$ dan $\mathrm{pH}$ dibawah 6 berdampak pada menurunnya daya larut asam fosfat $(\mathrm{P})$, Kaslium $(\mathrm{K})$ dan Magnesium(Mg). pH antara 3-5 dan pada suhu $26^{\circ} \mathrm{C}$ menyebabkan pertumbuhan penyakit yang disebabkan oleh jamur, salah satunya busuk akar (Mubarok, Salimah, Farida, Rochayat, \& Setiati, 2013). Pengukuran $\mathrm{pH}$ yang tepat akan memberikan media tanaman terbaik bagi tanaman untuk hidup. Penggunaan $\mathrm{pH}$ meter diwajibkan bagi pembuatan media tanam awal. Mitra pelatihan awalnya kurang mengerti tentang kegunaan $\mathrm{pH}$ dan bagaimana efeknya 
terlebih menggunakan $\mathrm{pH}$ meter pun tidak pernah sama sekali. Pemberian $\mathrm{pH}$ meter tentu langsung merangsang mitra untuk belajar cara menggunakan dan mengaplikasikan alat tersebut. Berikut suasana saat mitra belajar menggunakan $\mathrm{pH}$ meter.

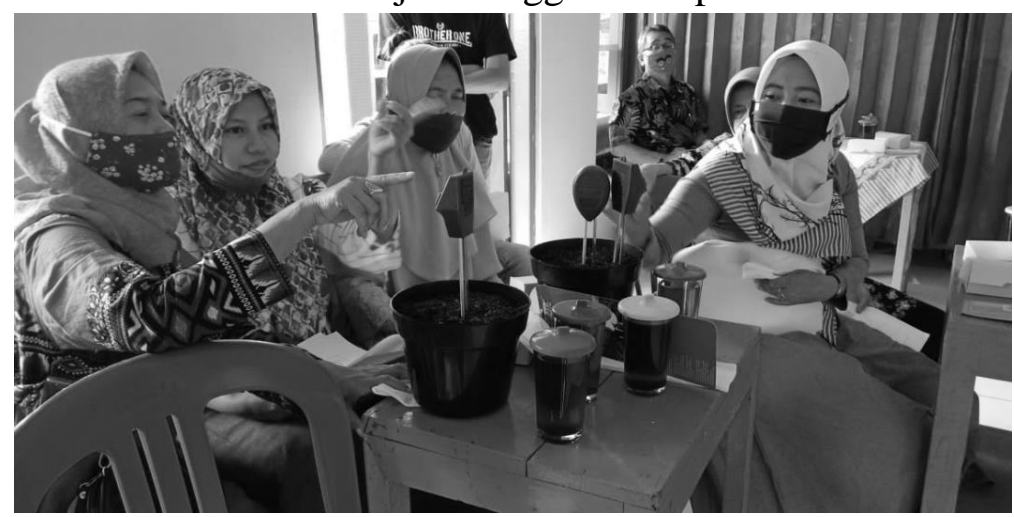

Gambar 1. Mitra Mengoperasikan pH meter dan moisture meter

Selain $\mathrm{pH}$, kelembaban menjadi topik yang diberikan kepada mitra. Pemahaman tentang pengelompokan jenis tanaman berdasarkan kelembaban yang dikehendaki perjenis tanaman diberikan dan pengelompokan itu terdiri dari Red zone 1-3 (sangat sedikit membutuhkan air, sehingga penyiraman sangat jarang dilakukan) seperti lidah buaya, kaktus, dan kembang sepatu. Green zone 4-5 (membutuhkan air dalam jumlah sedikit) sehingga penyiraman jarang dilakukan contoh: begonia, pohon bonsai, philodendron. Green zone 5-6, membutuhkan air dalam jumlah cukup banyak tetapi tidak sampai basah dalam waktu yang lama, contoh semangka, karet. Green zone 6-7, membutuhkan banyak air sehingga perlu kelembaban yang tinggi. Contoh amazon lily, sansivera, melati, dan Blue zone : tidak perlu penyiraman sama sekali dan kebanyakan hidup di air. Pengelompokan dimaksudkan agar mitra mengenali kebutuhan air per jenis tanaman hias yang mereka budidayakan sehingga membantu dalam menentukan penyiraman tanaman. Sebelum memperkenalkan alat ukur kelembaban salah satu peserta juga sempat mengalami kekeliruan dalam penyiraman philodendron melanochrysum, dimana peserta terlalu banyak menyiram dengan air sehingga tanaman justru semakin layu dan muncul gejala busuk akar.

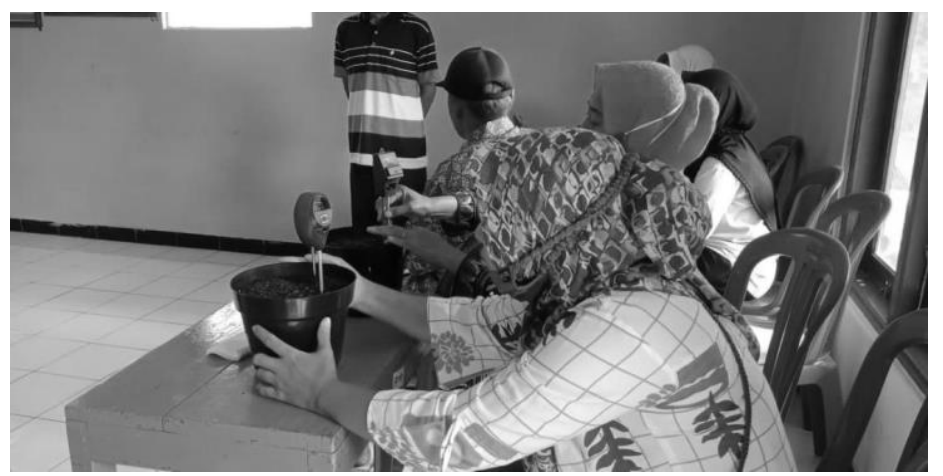

Gambar 2. Mitra melakukan pengukuran kelembaban dan intensitas cahaya

Intensitas cahaya menjadi pembahasan berikutnya dan setelah dijelaskan kepada peserta bahwa kebutuhan cahaya masing-masing tanaman akan menentukan penggunaan paranet yang selama ini digunakan oleh mitra. Peserta mengerti penggunaan dan aplikasi dilapangan penggunaan paranet dengan kode $25 \%, 55 \%, 60 \%$ dan $80 \%$. 
Salah satu komposisi media tanam yang biasa digunakan untuk tanaman Hias ialah campuran pakis, humus, pasir malang, dan cocopeat dengan perbandingan 2:1:1:1 yang umumnya baik untuk jenis aglonema dan monstera (Manullang, Hasibuan, \& Mawarni, 2019) Penggunaan pakis juga seringkali digunakan dalam budidaya tanaman hias, tetapi tidak disarankan karena pakis merupakan tanaman yang terancam punah. Media tanam yang dapat digunakan di antaranya ialah arang sekam, cocopeat, dan zeolite dengan komposisi yang berbeda. Hasil penelitian (Fatonah et al., 2020) menunjukkan bahwa penggunaan campuran zeolit dan arang sekam (1:3) dapat menghasilkan pertumbuhan tanaman mawar pot terbaik, sedangkan campuran zeolit dan cocopeat (1:3) atau (1:1) dapat menghasilkan tinggi tanaman dan jumlah daun terbanyak pada tanaman melati pot. Perbaikan yang dapat dilakukan oleh mitra adalah dengan melakukan pemilihan media tanaman yang sesuai dengan jenis tanaman hias yang dibudidayakan dan mengerti kelebihan dan kekurangan masing-masing media tanam. Misal jika $\mathrm{pH}$ rendah atau asam peserta dapat menambah kapur atau dolomit kedalam media tanam dan jika $\mathrm{pH}$ terlalu tinggi bisa ditambahkan pupuk kandang atau humus. Berkaitan dengan kelembaban, untuk tanaman yang tidak menyukai kelembaban tinggi mitra mengerti untuk memperbanyak komposisi pasir, sekam, pakis, sabut kelapa atau arang. Mitra juga mengerti bahwa penambahan media tersebut disesuaikan dengan cara penyiraman masing-masing mitra.

Berdasarkan hasil analisis dari uji pretest dan posttest yang dilakukan terhadap mitra dampingan didapatkan hasil nilai sig (2-tailed) $=0,027$ dengan taraf signifikansi 0,001 ( $\mathrm{p}<0,05$ ) skor rerata pretest 40,03 menjadi skor rerata posttest 70,30 . Rendahnya nilai pretest didapatkan karena memang mitra dampingan belum mengerti sama sekali mengenai $\mathrm{pH}$, sementara penggunaan air dan cahaya pada umumnya sudah banyak yang mengerti. Peserta pelatihan terlihat aktif dan banyak memberikan pertanyaan. Evaluasi pelatihan yang terdiri dari evaluasi terhadap materi pelatihan, trainer atau pelatih. Menurut peserta pelatihan, materi yang diberikan dan pelatihan yang diberikan sangat bermanfaat dan diharapkan mampu mengatasi juga kematian bibit akibat salah media tanam.

\section{KESIMPULAN}

Pelatihan perbaikan media tanam dengan menggunakan $\mathrm{pH}$ meter dan moisture meter yang telah dilaksanakan mampu meningkatkan pengetahuan mitra akan $\mathrm{pH}$ tanah, kelembaban tanah dan intensitas cahaya beserta peranannya bagi kehidupan tanaman hias. Mitra dapat memilih dan mencampur masing-masing media tanam yang disesuaikan dengan jenis tanaman yang diusahakan. Dalam pengaplikasian intensitas cahaya, terdapat keterbatasan ketersediaan paranet diwilayah lokal lokasi pengabdian. Kedepan diperlukan lebih kepada perbaikan manajemen tanaman dalam usaha tani usaha dikarenakan masih terdapat banyak tanaman yang dicampur dan berbeda jenis.

\section{UCAPAN TERIMA KASIH}

Terimakasih kepada PKK Ortega selaku mitra kegiatan Pengabdian pada Masyarakat Desa Tawangmangu, Kecamatan Tawangmangu, Kabupaten Karanganyar yang telah mengikuti kegiatan pengabdian masyarakat. Terima kasih kepada DRPMP Universitas Tunas 
GANESHA: Jurnal Pengabdian Kepada Masyarakat

Vol. 1, (2) Juli 2021

Pembangunan atas dana bantuan pelaksanaan pengabdian ini. Terimakasih kepada segenap pihak-pihak yang telah membantu dalam proses kegiatan pengabdian pada masyarakat ini.

\section{DAFTAR PUSTAKA}

Badan Pusat Statistik. (2018). Statistika Tanaman Hias Indonesia 2018. Badan Pusat Statistik. Jakarta: Badan Pusat Statistik.

Badan Pusat Statistik. (2020). Kecamatan Tawangmangu dalam Angka 2019. Karanganyar: Badan Pusat Statistik.

Fatonah, S., Setyawatiningsih, S. C., Khaswarina, S., Fatonah, S., Setyawatiningsih, S. C., \& Cahyadi, E. (2020). HERBAL Desa Danau Pulai Indah merupakan berkebun kelapa, kelapa sawit, dan karet . yang oleh masyarakat umumnya adalah masih tingginya penyakit infeksi dan penyakit Puskesmas , Rumah Sakit Umum Daerah penyembuhan penyakit adalah melalui pengobatan alter, 4(2).

Garuda News. (2021). Rekor, Dalam 1 Hari Lelang Dan Bursa Tanaman Hias Di Tawangmangu Tembus 1 Milyar. 9 Februari 2021, pp. 1-3. Retrieved from https://garudanews.id/2021/01/record-dalam-1-hari-lelang-dan-bursa-tanaman-hias-ditawangmangu-tembus-1-milyar/

Husnihuda, M. I., Sarwiti, R., \& Susilowati, Y. E. (2017). Respon Pertumbuhan dan Hasil Kubis Bunga (Brassica oleracea var. botrytis,L.) pada Pemberian PGPR Akar Bambu dan Komposisi Media Tanam. Jurnal Ilmu Pertanian Tropika Dan Subtropika, 2(1), 1316.

Kusno, T. S., \& Andri, K. B. (2011). Laporan Rancang Bangun Pengembangan Agribisnis Tanaman Bunga Krisan di Propinsi Jawa Timur. Surabaya.

Manullang, I. F., Hasibuan, S., \& Mawarni, R. (2019). Pengaruh Nutrisi Mix Dan Media Tanam Berbeda Terhadap Pertumbuhan Dan Produksi Tanaman Selada (Lactuca sativa) Secara Hidroponik Dengan Sistem Wick. BERNAS Agricultural Research Journal, 15(1), 82-90.

Mubarok, S., Salimah, A., Farida, F., Rochayat, Y., \& Setiati, Y. (2013). Pengaruh Kombinasi Komposisi Media Tanam dan Konsentrasi Sitokinin terhadap Pertumbuhan Aglaonema. Jurnal Hortikultura, 22(3), 251. https://doi.org/10.21082/jhort.v22n3.2012.p251-257

Tinaprilla, N., \& Pratiwi, C. P. (2017). Potensi Agribisnis Florikultura di Indonesia. In B. Krisnamurthi \& Harianto (Eds.), Mепијu AGRIBISNIS INDONESIA yang Berdaya Saing (2017th ed., pp. 89-105). Bogor: Raffi Offset. 